\title{
Inheritance of various yield contributing traits in maize (Zea mays L.) at low moisture condition
}

\author{
Muhammad Ahsan*, Amjad Farooq, Ihsan Khaliq, Qurban Ali, Muhammad Aslam and \\ Muhammad Kashif
}

Department of Plant Breeding and Genetics, University of Agriculture Faisalabad, Pakistan.

Accepted 9 January, 2013

\begin{abstract}
Six maize inbred lines were selected on the basis of their overall performances in preliminary screening. They were subjected to complete diallel analysis for various physio-genetic parameters under water deficit conditions. There were highly significant $(P<0.01)$ differences for all parameters, except leaf venation, among the inbred lines and their possible crosses. All traits showed additive gene action, except stomatal frequency and stomata size, which showed complete dominance and overdominance respectively. The strength of dominant and recessive genes for each trait was found different in each inbred. The narrow and broad sense heritabilities for the traits under study ranged between 35 to 80 and 32 to $78 \%$ respectively. However, stomata frequency and size might be useful while selecting maize inbred lines for hybrid seed production under limited water conditions and all other traits might be used while selecting inbred lines for synthetic genotype development.
\end{abstract}

Key words: Drought, corn, stress breeding, gene action, physiology.

\section{INTRODUCTION}

Maize plays a pivotal role in more food production program to cope with ever increasing population of Pakistan. It is used in the human diet in both fresh and processed forms. Besides providing food for human beings and feed for animals, it is used extensively as raw material in industry that benefits a large proportion of the world. The value addition has been an economic driver in the specialty corn markets (Hallauer and Miranda, 1988). The global food supply demand model predicts that global demand for maize will increase from $526 \mathrm{M}$ tons to $784 \mathrm{M}$ tons from 1993 to 2020, with most of the increased demand coming from developing countries (Rosegrant et al., 1999). Plants may experience many distinct abiotic stresses in the fields like water stress, salinity and temperature extreme either continuously or discontinuously at different times during the growing season (Tester and Basic, 2005). Abiotic stresses limit crop productivity (Araus et al., 2002). According to Jamieson et al. (1995) water requirement of maize at the time of tesseling is 135

*Corresponding author. E-mail: ahsanpbg@uaf.edu.pkm or saim_1692@yahoo.com. $\mathrm{mm} /$ month $(4.5 \mathrm{~mm} /$ day) and this requirement may increase up to $195 \mathrm{~mm} /$ month $(6.5 \mathrm{~mm} /$ day $)$ during hot windy conditions. The rainfall in Pakistan is low and irregular (less than $100 \mathrm{~mm}$ ) in maize growing areas and $70 \%$ of total rainfall occurs in July to September (Anonymous, 2003).

Drought results in reduced crop yield, pasture deterioration and livestock death. It strongly affects the production of cereals and poses a serious threat to the food security of households, countries and even entire subcontinents. In future, the destructive impact of drought may grow, as the climate change becomes a reality. The maize crops may experience reductions in grain yields when subjected to water deficit during the critical period of crop cycle from tesseling stage to beginning of grain filling. During 1998/1999 long drought period, $48.8 \mathrm{~mm}$ rain only allowed grain yield of 8 t/ha while during the year 2002/03 a short duration drought at critical period reduced grain yield less than to $2 \mathrm{t} / \mathrm{ha}$, resulting from the effects on the ear per plant and kernel per ear (Bergamaschi et al., 2004). The use of genetics to improve drought tolerance and provide yield stability is an important part of the solution to this problem. Agronomical interventions also have their importance, since 
genetic solutions are unlikely to close more than $30 \%$ of the gap between potential and realized yield under water stress (Edmeades et al., 2004). However, improved genetics can be packed in a seed and easily be adapted than improved agricultural practices that depend more heavily on input availability, infrastructure, and access to markets and skill in crop and soil management (Campos et al., 2004).

There are two pre-requisites of evolving new lines, one is the existence of variations for the character and the second is the heritability of that character. The genetically controlled variations for drought tolerance can only enable the plant breeders to evolve drought tolerant maize lines. The previous research is evident that variation for drought tolerance exists in various crop species like wheat (Guttieri et al., 2001) and in maize (Frova et al., 1999). Because of this rich genetic diversity for drought, new methodologies can help to evolve drought tolerant varieties. Hybrids of the parents have more diversity yield than of similar parents (Troyer et al., 1998). This research program was initiated to examine the existence of variability and its genetic basis and to evaluate a set of inbred lines of maize to obtain information on the relative importance of general and specific combining ability for grain yield and its gene action for various physio-genetic traits under drought conditions.

\section{MATERIALS AND METHODS}

\section{Preliminary screening}

The experimental material was made of 25 maize inbred lines, collected from different research institutions of Pakistan and was evaluated against drought stress of below $50 \%$ field capacity (FC) moisture deficit level. The moisture level was maintained using moisture meter ( $\Delta \mathrm{T}-\mathrm{NH} 2$, Cambridge, England). An experimental unit was a Polythene bag $(18 \times 9 \mathrm{~cm})$ filled with sand containing one seedling. Ten seedlings of each inbred line were grown in each of the established four replications. Two replications were harvested after 15 days and the rest after 20 days from date of sowing. On the basis of their survival rate and better performance under water deficit condition, six inbred lines, including 20P2-1, L51, L7-2, 70NO2-2, 150P1 and 150P2-1 were selected as drought tolerant and further evaluated on the field under $50 \%$ water deficit conditions as recommended irrigation.

\section{Final assessment phase}

The inbred lines selected at the preliminary screening were crossed in full diallel fashion in spring season of 2007 to generate genetic material for final assessment and hybrid $\left(F_{1}\right)$ seeds were collected. The hybrid seeds $\left(F_{1}\right)$ along with the parental inbred lines were planted in triplicate in a randomized complete block design during autumn 2007. Sowing was done in rows at two seeds per hill and later thinned to one plant per stand at 4 to 5 leaf stage. The intrarow and inter-row spacings were 15 and $75 \mathrm{~cm}$, respectively. $50 \%$ water stress was given by reducing half number of irrigations alternatively. Five tagged plants were selected from each entry at random and data were recorded for the following physio-genetic traits.

\section{Leaf venation}

Leaf venation was examined with the help of microscope (NIKONH3, JAPAN). The low power of microscope (10X) was used to examine the leaf venation. These observations were recorded from different places of each leaf slide.

\section{Stomatal frequency}

The stomata frequency was observed from the upper surface of the middle part of the leaf blades. Two leaves from each of ten plants of each entry were taken. These leaf samples were placed in Carnoy's solution (Absolute alcohol 100 parts, Chloroform pure 50 parts, Glacial acetic acid 16 parts) for $24 \mathrm{~h}$ to arrest stomatal movement and to remove chlorophyll. The leaves were washed in acetone and stored in formalin solution. The cleaned leaves were examined under (10X) objective of the microscope and numbers of stomata were counted.

\section{Stomata size}

Stomata size was measured with the help of ocular micrometer using microscope (NIKON-H3, JAPAN). The medium power (40X) was used to examine the stomata size. Ocular micrometer was calibrated with the help of stage micrometer. The length and width of the stomata was measured in microns. These observations were recorded from three different places of each leaf and area was calculated by using the following formula:

Area $=$ Length $\times$ Width

\section{Epidermal cell size}

Epidermal cell size was also measured with the help of ocular micrometer using microscope (NIKON-H3, JAPAN). The medium power (40X) was used to examine the epidermal cell size. Ocular micrometer was calibrated with the help of stage micrometer. The length and width of the epidermal cell size was measured in microns. These observations were recorded from three different places of each leaf and area was calculated by using the following formula:

Area $=$ Length $\times$ Width

\section{Silk elongation rate}

Silk elongation rate was recorded following Anderson et al. (2004). Five cobs from five tagged plants of each entry were selected to record the data under $50 \%$ stress condition. On the day of first silk appearance, the silk length was marked as zero. Length of silk was recorded daily in the morning between 7.00 to $8.00 \mathrm{am}$. Silks were kept covered with butter paper bag to rule out any chance of pollination during this period.

Elongation rate $=$ Total length of silk/Total number of days after first silk appearance

\section{Anthesis to silking interval}

The anthesis to silking interval is the difference between the first day of anthesis to the day of silk appearance. The five tagged plants were observed for the date of anthesis and then the date of silking. Then, the days between anthesis to silking of each plant 
Table 1. Mean squares of analysis of variance for six inbred lines along with all their direct and indirect crosses for various parameters in maize.

\begin{tabular}{lcccccccc}
\hline S.O.V & df & $\begin{array}{c}\text { Leaf } \\
\text { venation }\end{array}$ & $\begin{array}{c}\text { Stomata } \\
\text { frequency }\end{array}$ & $\begin{array}{c}\text { Stomata } \\
\text { size }\end{array}$ & $\begin{array}{c}\text { Epidermal } \\
\text { cell size }\end{array}$ & $\begin{array}{c}\text { Silk elongation } \\
\text { rate }\end{array}$ & $\begin{array}{c}\text { Anthesis to } \\
\text { silking interval }\end{array}$ & $\begin{array}{c}\text { Grain yield } \\
\text { per plant }\end{array}$ \\
\hline Replication & 2 & $1.0278^{\text {ns }}$ & $0.5832^{\text {ns }}$ & $5147^{\text {ns }}$ & $47093^{\text {ns }}$ & $0.6025^{\text {ns }}$ & $0.1111^{\text {ns }}$ & $4.22^{\text {ns }}$ \\
Genotype & 35 & $0.5976^{\text {ns }}$ & $1.0303^{\star *}$ & $15071^{* *}$ & $146088^{* *}$ & $0.8987^{* *}$ & $0.5402^{* *}$ & $193.62^{* *}$ \\
Error & 70 & 0.3992 & 0.3207 & 4249 & 31532 & 0.4242 & 0.1378 & 66.43 \\
\hline
\end{tabular}

*, Significance at $5 \%$; ${ }^{* *}$, significance at $1 \%$ probability level; ns, non significant; SOV, source of variation.

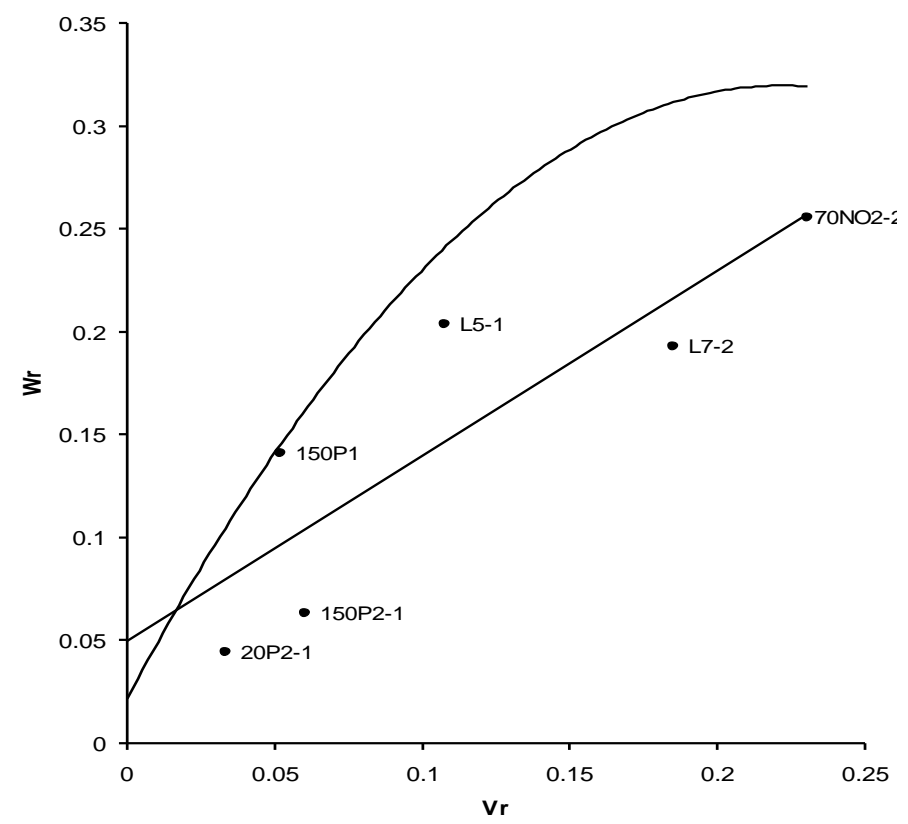

Figure 1. Leaf venation.

were counted and the mean of five plants was calculated.

\section{Grain yield per plant}

The cobs from five selected plants of each entry were harvested and threshed separately. The grains from each plant were weighed in grams using an electronic balance (OHAUS-GT4000, USA) and their mean was calculated.

\section{Statistical analysis}

The recorded data of all the parameters were analyzed by using analysis of variance (ANOVA) (Steel et al., 1997) in ordered to determine the variability among the crosses. The parameters showing significant genotypic differences among the thirty hybrids and six parents were further analyzed to determine gene action by following additive-dominance model developed by Hayman (1954) and Jinks (1954, 1955, 1956).

\section{RESULTS}

Results indicate significant differences at $0.01 \%$ probability level for all the parameters among the genotypes (parents and crosses) except leaf venation (Table 1). In order to check the adequacy of the data for simple additive-dominance model, after analysis of variance, the data were subjected to joint regression analysis. For this purpose, the mean values of each cross and six parents were arranged (Table 3$)$. Variance $(\mathrm{Vr})$ and covariance $(\mathrm{Wr})$ values were used to construct $\mathrm{Vr} / \mathrm{Wr}$ graph (Figures 1 to 6 ) to observe the mode of gene action and distribution of dominant and recessive genes.

\section{Leaf venation}

Results of joint regression analysis (Table 2) suggested that data for leaf venation were fit for simple additivedominance model. The results of Figure 1 exhibits that the regression line intercepted the Wr-axis above the point of origin, which indicated partial dominance with additive type of gene action. The regression line did not deviate significantly from unit slope, which suggested the absence of non-allelic interactions. The position of array points on regression line (Figure 1) showed that inbred line 20P2-1 had maximum dominant genes for leaf venation, being the closest to the point of origin while inbred line 70NO2-2 possessed maximum recessive genes being the farthest from origin. Table 3 shows that inbred line 70NO2-2 possessed maximum array mean (4.47) showing its best general combining ability and L7-2 secured minimum mean value (3.93) from all the inbred line, while within arrays of crosses, the cross 70NO2$2 \times$ L7-2 having the highest value (5.0) showed the best specific combining whereas $150 \mathrm{PI} \times \mathrm{L} 7-2$ secured minimum mean value (3.33) effects for the trait of leaf venation. The presence of additive genetic effects described moderate estimates (Table 3 ) of narrow sense heritability $(0.36)$ and broad sense heritability with value of (0.32) indicative of additive with partial dominance type of gene action suggesting the feasibility of selection in early generations.

\section{Stomatal frequency}

In case of stomata frequency, the values of $\mathrm{Wr}$ and $\mathrm{Vr}$ plotted a graph (Figure 2) and the results of joint 
Table 2. Scaling test (Joint regression analysis) of plant parameters in maize.

\begin{tabular}{|c|c|c|c|c|c|}
\hline \multirow{2}{*}{ Parameter } & \multicolumn{3}{|c|}{ Regression coefficient } & \multirow{2}{*}{ Remark } & \multirow{2}{*}{ Conclusion } \\
\hline & B & $b=0$ & $b=1$ & & \\
\hline Leaf venation & $0.90 \pm 0.26$ & $3.44^{*}$ & 0.37 & $\begin{array}{l}\text { b value deviate significantly } \\
\text { from zero but not from unity }\end{array}$ & $\begin{array}{l}\text { The data were adequate for simple } \\
\text { additive-dominance model }\end{array}$ \\
\hline Stomata frequency & $1.09 \pm 0.28$ & $3.79^{*}$ & -0.32 & -do- & -do- \\
\hline Stomata size & $0.91 \pm 0.25$ & $3.56^{*}$ & 0.32 & -do- & - do- \\
\hline Epidermal cell size & $1.05 \pm 0.20$ & $5.27^{*}$ & -0.29 & -do- & -do- \\
\hline Silk elongation rate & $0.91 \pm 0.24$ & $3.70^{*}$ & 0.36 & -do- & -do- \\
\hline Anthesis to silking interval & $0.95 \pm 0.15$ & $6.02^{*}$ & 0.30 & - do- & - do- \\
\hline Grain yield per plant & $0.93 \pm 0.15$ & $5.90^{*}$ & 0.42 & -do- & -do- \\
\hline
\end{tabular}

- $t$ of $b_{0}$ should be $>2.7764$; - $t$ of $b_{1}$ should be $<2.7764$.

Table 3. Mean values of parents and crosses.

\begin{tabular}{|c|c|c|c|c|c|c|c|}
\hline Inbred line & $\begin{array}{c}\text { Leaf } \\
\text { venation }\end{array}$ & $\begin{array}{c}\text { Stomata } \\
\text { frequency }\end{array}$ & $\begin{array}{c}\text { Stomata } \\
\text { size }\end{array}$ & $\begin{array}{c}\text { Epidermal cell } \\
\text { size }\end{array}$ & $\begin{array}{c}\text { Silk elongation } \\
\text { rate }\end{array}$ & $\begin{array}{c}\text { Anthesis to } \\
\text { silking interval }\end{array}$ & $\begin{array}{c}\text { Grain yield } \\
\text { per plant }\end{array}$ \\
\hline 20P2-1 & 4.00 & 11.67 & 1078.82 & 3207.05 & 8.20 & 5.93 & 126.13 \\
\hline L5-1 & 4.33 & 11.93 & 1127.00 & 2628.03 & 7.39 & 5.80 & 111.40 \\
\hline L7-2 & 3.00 & 12.07 & 1127.82 & 3086.18 & 8.18 & 5.80 & 109.10 \\
\hline $70 \mathrm{NO} 2-2$ & 5.00 & 12.13 & 1081.27 & 2773.40 & 7.18 & 5.53 & 101.13 \\
\hline 150P1 & 4.33 & 10.20 & 1161.30 & 3549.23 & 8.29 & 7.00 & 103.27 \\
\hline 150P2-1 & 4.67 & 12.53 & 1011.03 & 3163.77 & 6.62 & 5.80 & 112.56 \\
\hline \multicolumn{8}{|l|}{ Crosses } \\
\hline 20P2-1×L5-1 & 4.33 & 12.20 & 1171.10 & 3278.10 & 7.49 & 6.87 & 114.29 \\
\hline $20 \mathrm{P} 2-1 \times \mathrm{L} 7-2$ & 4.67 & 13.07 & 981.63 & 3303.42 & 6.85 & 5.87 & 110.64 \\
\hline $20 \mathrm{P} 2-1 \times 70 \mathrm{NO} 2-2$ & 4.67 & 12.27 & 1136.80 & 3336.90 & 7.35 & 5.20 & 119.18 \\
\hline $20 \mathrm{P} 2-1 \times 150 \mathrm{P} 1$ & 4.00 & 11.27 & 1324.63 & 3314.03 & 8.16 & 4.81 & 112.01 \\
\hline $20 \mathrm{P} 2-1 \times 150 \mathrm{P} 2-1$ & 4.00 & 11.27 & 1033.90 & 3306.68 & 7.29 & 4.80 & 116.68 \\
\hline Mean & 4.33 & 12.02 & 1129.61 & 3307.83 & 7.43 & 5.51 & 114.56 \\
\hline L5-1×20P2-1 & 4.00 & 11.13 & 1266.65 & 3221.75 & 6.25 & 6.13 & 109.13 \\
\hline L5-1×L7-2 & 3.67 & 10.67 & 1220.92 & 3398.15 & 6.81 & 5.93 & 110.47 \\
\hline L5-1×70NO2-2 & 4.67 & 11.27 & 1327.90 & 3670.10 & 7.42 & 5.27 & 106.29 \\
\hline L5-1×150P1 & 4.00 & 11.73 & 1141.70 & 3232.37 & 9.12 & 5.73 & 112.42 \\
\hline L5-1×150P2-1 & 4.00 & 11.93 & 1233.98 & 3118.03 & 7.54 & 5.40 & 139.24 \\
\hline Mean & 4.07 & 11.35 & 1238.23 & 3328.08 & 7.43 & 5.69 & 115.51 \\
\hline L7-2×20P2-1 & 3.67 & 13.93 & 1039.62 & 2654.17 & 7.45 & 4.87 & 119.19 \\
\hline L7-2xL5-1 & 4.00 & 10.93 & 1292.78 & 3164.58 & 7.67 & 5.73 & 119.89 \\
\hline L7-2×70NO2-2 & 3.33 & 12.80 & 1229.08 & 2944.08 & 5.50 & 4.53 & 153.14 \\
\hline L7-2×150P1 & 4.33 & 12.87 & 1144.15 & 3278.92 & 7.10 & 5.73 & 91.65 \\
\hline L7-2×150P2-1 & 4.33 & 12.60 & 1233.98 & 3515.75 & 7.43 & 5.93 & 90.36 \\
\hline Mean & 3.93 & 12.63 & 1187.92 & 3111.5 & 7.03 & 5.36 & 114.85 \\
\hline $70 \mathrm{NO} 2-2 \times 20 \mathrm{P} 2-1$ & 4.33 & 11.67 & 1148.23 & 3354.05 & 7.14 & 4.73 & 102.43 \\
\hline $70 \mathrm{NO} 2-2 \times \mathrm{L} 5-1$ & 5.00 & 9.93 & 1046.15 & 3801.58 & 7.98 & 6.00 & 112.65 \\
\hline 70NO2-2×L7-2 & 4.00 & 13.53 & 1128.63 & 2833.83 & 6.68 & 5.90 & 115.51 \\
\hline 70NO2-2×150P1 & 4.67 & 12.47 & 1208.67 & 2707.25 & 5.87 & 5.33 & 108.63 \\
\hline $70 \mathrm{NO} 2-2 \times 150 \mathrm{P} 2-1$ & 4.33 & 11.93 & 1108.22 & 2719.50 & 7.24 & 5.33 & 96.57 \\
\hline Mean & 4.47 & 11.91 & 1127.98 & 3083.24 & 6.98 & 5.46 & 107.16 \\
\hline
\end{tabular}


Table 3. Contd.

\begin{tabular}{|c|c|c|c|c|c|c|c|}
\hline $150 \mathrm{P} 1 \times 20 \mathrm{P} 2-1$ & 4.33 & 10.67 & 1262.40 & 3920.00 & 6.97 & 5.80 & 94.38 \\
\hline $150 \mathrm{P} 1 \times \mathrm{L} 5-1$ & 4.33 & 13.87 & 1046.97 & 3259.32 & 8.00 & 4.67 & 132.10 \\
\hline $150 \mathrm{P} 1 \times \mathrm{L} 7-2$ & 3.33 & 10.93 & 1027.37 & 3334.45 & 6.40 & 5.60 & 90.19 \\
\hline $150 \mathrm{P} 1 \times 70 \mathrm{NO} 2-2$ & 4.00 & 11.80 & 1073.92 & 3327.92 & 6.71 & 5.93 & 141.91 \\
\hline 150P1×150P2-1 & 4.67 & 11.47 & 1143.33 & 3056.78 & 8.26 & 5.27 & 119.80 \\
\hline Mean & 4.13 & 11.75 & 1110.80 & 3379.69 & 7.27 & 5.45 & 115.68 \\
\hline $150 P 2-1 \times 20 P 2-1$ & 4.00 & 11.93 & 1064.93 & 3527.18 & 8.16 & 5.47 & 95.11 \\
\hline 150P2-1 $\times$ L5-1 & 4.67 & 9.60 & 1247.05 & 3521.47 & 7.08 & 4.49 & 140.63 \\
\hline 150P2-1×L7-2 & 4.00 & 9.93 & 989.80 & 3477.37 & 6.95 & 4.53 & 100.83 \\
\hline 150P2-1 $\times 70$ NO2-2 & 4.00 & 10.60 & 1192.33 & 4847.73 & 7.34 & 4.53 & 113.11 \\
\hline $150 \mathrm{P} 2-1 \times 150 \mathrm{P} 1$ & 4.33 & 12.13 & 1091.07 & 2850.98 & 7.09 & 6.67 & 107.50 \\
\hline Mean & 4.20 & 10.83 & 1117.04 & 3644.95 & 7.32 & 5.13 & 111.44 \\
\hline$\left(h^{2}{ }_{n s}\right)$ & 0.36 & 0.56 & 0.52 & 0.80 & 0.62 & 0.68 & 0.58 \\
\hline$\left(h^{2}{ }_{b s}\right)$ & 0.32 & 0.35 & 0.51 & 0.78 & 0.55 & 0.67 & 0.50 \\
\hline
\end{tabular}

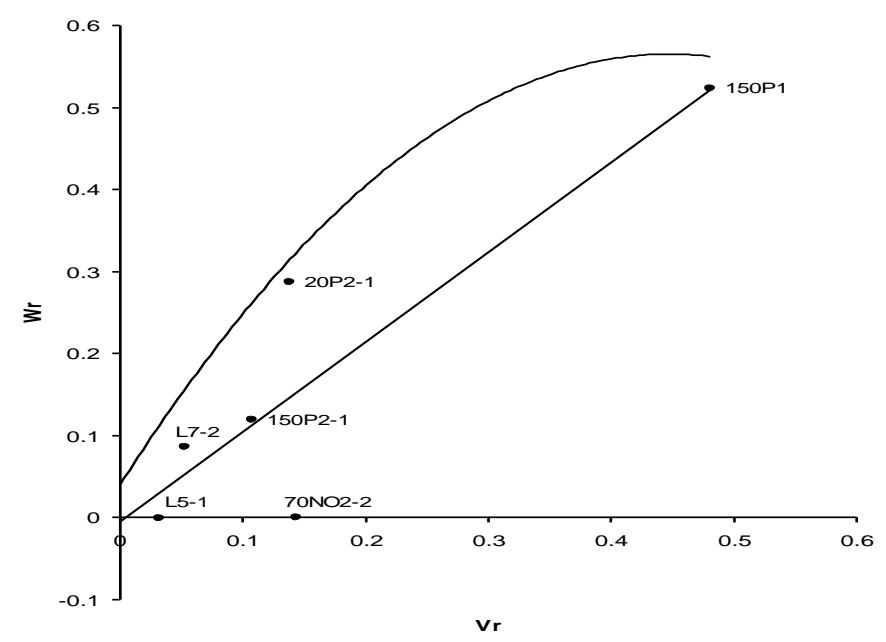

Figure 2. Stomatal frequency

regression analysis (Table 2) suggested the fitness of data for additive-dominance model. The graphical representation showed that the regression line (b) passed through the origin indicating the complete dominant gene action for stomatal frequency. The position of the array points (Figure 2) on regression line exhibited that the inbred line L5-1 being closer to the origin received maximum dominant genes and 150P1secured maximum recessive genes being farther from the origin. Table 3 reveals that inbred line L7-2 with higher array mean (12.63) proved to be the best general combiner while the cross L7-2×20P2-1 showed the highest specific combining ability as it secured maximum value (13.93). The stomatal frequency (Table 3 ) showed narrow sense heritability $(0.56)$ but broad sense heritability (0.35) estimates, suggesting the presence of additive genetic

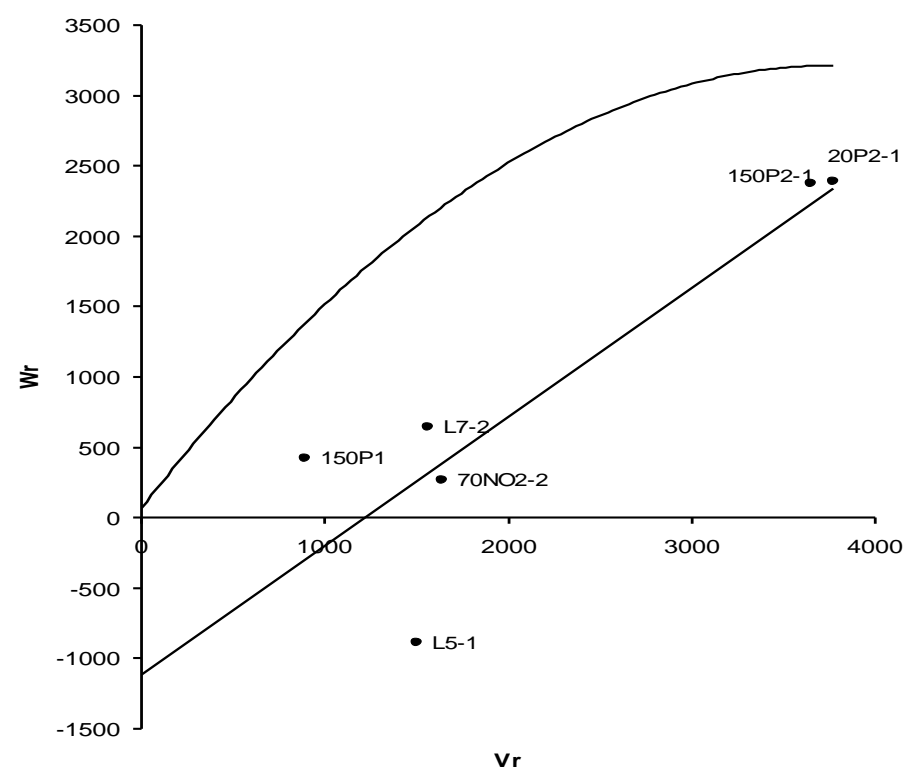

Figure 3. Stomatal size

effects.

\section{Stomata size $\left(\mu \mathrm{m}^{2}\right)$}

Results of the joint regression analysis (Table 2) proved the fitness of data for genetic analysis. The inheritance of stomata size was determined as over dominance gene action because the regression line intercepted the Wraxis below the origin. As the position of array points on regression line was concerned, inbred line 150P1 secured maximum dominant genes being the nearest to origin than the 20P2-1 being the farthest from origin 


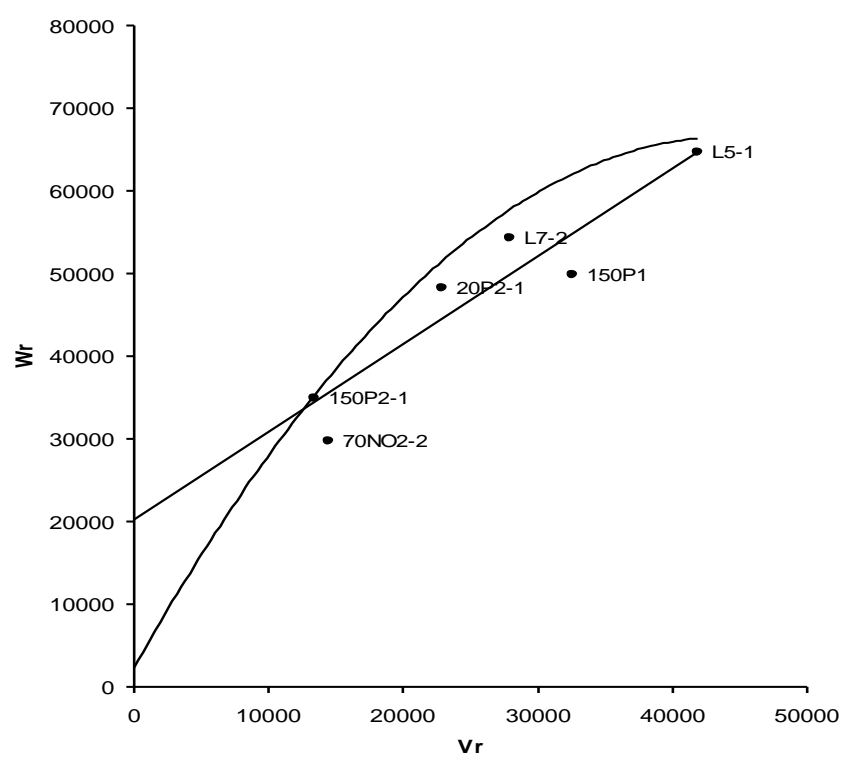

Figure 4. Epidermal cell size

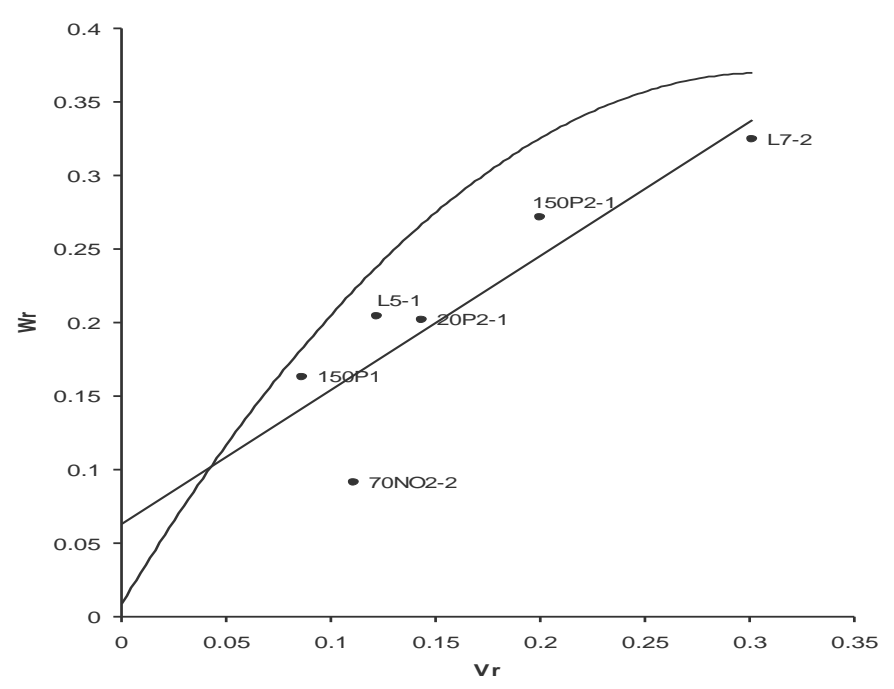

Figure 5. Silk elongation rate

(Figure 3). The data of mean values (Table 3 ) revealed that inbred line L5-1 proved to be the best general combiner with mean value of $1238.23 \mu \mathrm{m}^{2}$. The cross L5$1 \times 70 \mathrm{NO} 2-2$ exhibited the maximum specific combining ability with mean value of $1327.90 \mu \mathrm{m}^{2}$. The estimates of heritability in Table 3 showed narrow and broad sense heritability 0.52 and 0.51 respectively that was an indication for the presence of complete dominance gene action.

\section{Epidermal cell size}

The results of the joint regression analysis (Table 2) proved that the data was fit for genetic analysis and fully adequate for additive-dominance model. The graphical representation (Figure 4) revealed that regression line (b) intercepted the Wr-axis above the origin indicating additive type of gene action involved in the expression of this character. The relative position of array point on the regression line determined that inbred line 70NO2-2 received maximum dominant genes and inbred line L5-1 secured maximum recessive genes because of their closer and farther positions from the origin respectively. The mean values (Table 3 ) revealed that inbred line 150P1 proved to be the best general combiner with maximum mean value of $3379.69 \mu^{2}$ whereas inbred line L5-1 proved to be the poor general combiner because of the minimum mean value of $\left(3083.24 \mu \mathrm{m}^{2}\right)$. The cross $20 \mathrm{P} 2-1 \times 150 \mathrm{P} 1$ secured the highest specific combining ability mean value of $3801.58 \mu \mathrm{m}^{2}$ and L7$2 \times 20 \mathrm{P} 2-1$ proved to be the poor specific combiner with mean value of $2654.17 \mu^{2}$. There was high narrow sense heritability $(0.80)$ and broad sense heritability (0.78) respectively.

\section{Silk elongation rate}

The results of joint regression analysis (Table 2) suggested that data were quite valid for additivedominance model. Figure 5 illustrates the additive type of gene action controlling the inheritance of this trait as the regression line intercepted the Wr-axis above the point of origin. The position of array points on regression line concluded that inbred line $70 \mathrm{NO} 2-2$ received maximum dominant gene and inbred line L7-2 secured maximum recessive genes being the closest and the farthest relative to the origin, respectively. The inbred lines 20P21 AND L5-1 proved to be the best general combiner with highest mean value of $7.43 \mathrm{~cm}$ while inbred line $70 \mathrm{NO} 2-2$ possessed minimum mean value of (6.98). The cross L5$1 \times 150 \mathrm{P} 1$ also proved to be the best specific combiner with the highest cross value of $9.12 \mathrm{~cm}$ while L5-1×20P21 proved to be the poorest specific combiner with mean value of $6.25 \mathrm{~cm}$ (Table 3). As indicated by Table 3, that narrows sense heritability (0.62) as well as broad sense heritability (0.55) was moderate due to the additive type of inheritance pattern in this trait. Moderate narrow sense heritability suggested that improvement could be made through individual plant selection in the later generations.

\section{Anthesis to silking interval}

The joint regression analysis (Table 2) suggested that data were suitable for additive-dominance model. As the regression line passed through $\mathrm{Wr}$-axis above the point of origin, it signified that the inheritance of this trait was controlled by additive type of gene action. The position of array points on regression line (Figure 6) illustrated that inbred line 70NO2-2 received maximum dominant gene 


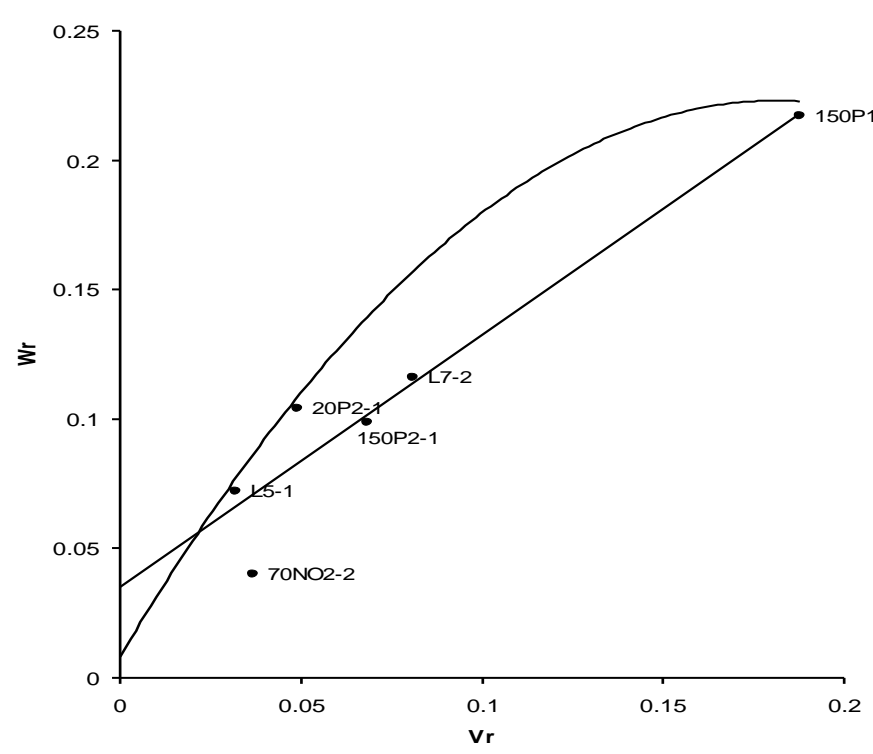

Figure 6. Anthesis to silking interval.

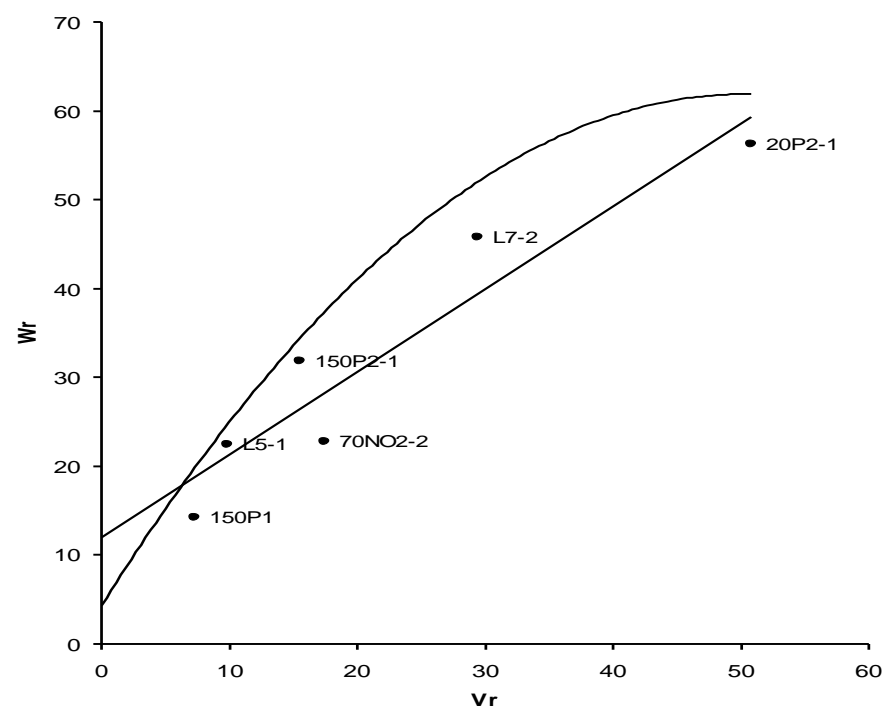

Figure 7. Grain yield per plant

and inbred line 150P1 secured maximum recessive genes being the closest and the farthest relative to the origin, respectively. The inbred line L5-1 proved to be the best general combiner with highest mean value of 5.69 whereas inbred line 150P2-1 proved to be the poorest general combiner with mean value of 5.13 for anthesis to silking interval. The cross 20P2-1 $\times$ L5-1 also proved to be the best specific combiner with the highest cross value of 6.87 and cross L7-2×70NO2-2 exhibited poorest mean value of 4.53 for specific combining ability. The narrow sense heritability (0.68) as well as broad sense heritability (0.67) was due to the additive type of inheritance pattern in this parameter (Table 3 ).

\section{Grain yield per plant}

The results of regression analysis (Table 2 ) indicated the adequacy of the data for genetic analysis. Additive type of gene action was observed in the inheritance of this trait as the regression line (b) passed through the $\mathrm{Wr}$-axis above the point of origin (Figure 7). The distribution of array points along with the regression line (b) indicated that inbred line 150P1 received most of the dominant genes because of its presence nearest to the origin while inbred line 20P2-1 secured maximum recessive genes being the farthest from origin respectively. Table 3 suggests that inbred line L5-1 and 150P1 had good general combining ability as it secured maximum array mean value (115.51 and $115.68 \mathrm{~g}$ ) whereas 70NO2-2 showed minimum mean value $107.16 \mathrm{~g}$ as within arrays. The cross L7-2 $\times$ 70NO2-2 showed good specific combining ability effects and secured the highest value $153.14 \mathrm{~g}$ whereas the cross $150 \mathrm{P} 1 \times \mathrm{L} 5-2$ showed the lowest specific combining ability effects and secured the value of $90.19 \mathrm{~g}$. Table 3 shows the values of narrow sense heritability $(0.58)$ and broad sense heritability $(0.50)$ that was an indication of the presence of additive gene action.

\section{DISCUSSION}

For general combining ability (GCA), 20P2-1 was the best general combiner for the epidermal cell size and grain yield and L7-2 for stomata size. The inbred line 70NO2-2 exhibited best GCA for leaf venation and 150P1 proved a good general combiner for stomata size, silk elongation rate and anthesis to silking interval. The

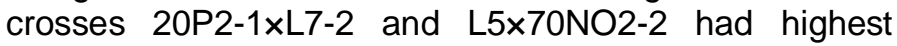
specific combining ability (SCA) values for grain yield per plant and leaf venation respectively whereas 20P21×150P1 exhibited best SCA for parameters like stomata size, epidermal cell size and anthesis to silking interval. Regarding inheritance patterns, over dominance was found to control stomata size and these results are in accordance with the results of Tabassum et al. (2005) under normal and water stress conditions. Negative combining ability results for stomata size were found which were according to the findings of Saeed et al. (2001). Regarding epidermal cell size, additive effects were found which were supported by Mahmood et al. (2003). In this present study, silk elongation rate increased at value which was supported by Carcova et al. (2003). For anthesis to silking interval, additive gene action with partial dominance was found in contrast to the results of Afarinesh et al. (2005) and diverse anthesis to silking interval which was supported by the results of Sari et al. (1999) and Ribaut et al. (1996). For grain yield per plant, low specific combining ability effects were observed and these were supported by the report of Gissa et al. (2007). Water stress reduces grain yield 
(Kebede et al., 2001; Ge et al., 2005). Additive effects for this trait were reported by Farshadfar et al. (2002).

\section{REFERENCES}

Afarinesh A, Farshadfar E, Choukan R (2005). Genetic analysis of drought tolerance in maize (Zea mays L.) using diallel method. Seed Plant 20:457-473.

Anderson SR. Lauer MJ. Schoper JB. Richard MS (2004). Pollination timing effects on kernel set and silk receptivity in four maize hybrids. Crop Sci. 44:464-473.

Anonymous (2003). Strategic plan of the Pakistan Council of Research in Water Resources. Pakistan Council of Research in Water Resources Islamabad.

Araus JI. Slafer GA. Reynolds MP, Toyo C (2002). Plant breeding and drought in $\mathrm{C}_{3}$ cereals, what should we breed for. Ann. Bot. 89:925940.

Bergamaschi H, Dalmago AG, Bergonci IJ, Bianchi MAC. Muller GA, Comiran F, Heckler MMB (2004). Water supply in the critical period of maize and the grain production. Pesquisa Agropecuaria Brasileira. 39:831-839.

Campos H, Cooper M, Habben JE, Edmeades GO, Schussler JR (2004). Improving drought tolerance in maize: A view from industry. Field Crops Res. 90:19-34.

Carcova J, Andrieu B, Otegui ME (2003). Silk elongation in maize relationship with flower development and pollination. Crop Sci. 43:914-920.

Edmeades GO, Banziger M, Schussler JR, Campos H (2004). Improving abiotic stress tolerance in maize: a random or planned process? In: Proceedings of the Arnel R. Hllauer International Symposium on Plant Breeding. Mexico City, 17-22 August 2003, lowa State University Press, in press.

Farshadfar E, Afarinesh A, Sutka J (2002). inheritance of drought tolerance in maize. Cereal Res. Commun. 30:285-291.

Frova C, Villa M, Sari GM, Krajewski P, Fonzo ND (1999). Genetic analysis of drought tolerance in maize by molecular markers. I. Yield components. Theor. Appl. Genet. 99:280-288.

Ge T, Sui F, Bai L, Lu Y, Zhou G (2005). Effect of different soil water content obn photosynthetic character and pod yields of summer maize. J.Shanghai. Jiaotong Univ. Sci. 23:143-147.

Gissa DW, Zelleke H, Labuschagne MT. Hussien T, Singh H (2007). Heterosis and combining ability for yield and its components in selected inbred lines. South Afr.J. Plant Soil. 24:133-137.

Guttieri MJ, Jeffrey C, O‘Brien SK, Souza E (2001). Relative sensitivity of spring wheat grain yield and quality parameters to moisture deficit. Crop Sci. 41:327-335.

Hallauer AR. Miranda JB (1988). Quantitative genetics in maize breeding. $2^{\text {nd }}$ ed. lowa State Univ. Press, Ames, IA. p. 468.
Hayman BJ (1954). The analysis of variance of diallel tables. Biometrics 10:235-244.

Jamieson PD, Martin RJ, Francis GS (1995). Drought influence on grain yield of Barley, wheat and maize. NZ J. Crop. Hortic. Sci. 23:55-66.

Jinks JL (1954). The analysis of continuous variation in diallel crosses of Nicotiana rustica L. Varieties. Genetics 39:767-788.

Jinks JL (1955). A survey of genentical bases of heterosis in variety of diallel crosses. Heredity 9:223-238.

Jinks $\mathrm{JL}$ (1956). The $\mathrm{F}_{2}$ and back cross generation from set of diallel crosses. Heredity 1:1-30.

Kebede H, Subudhi PK, Rosenow TD, Nguyen HT (2001). Quantitative trait loci influencing drought tolerance in grain sorghum (Sorghum bicobr LMoench). Theor. Appl. Genet. 103:266-276.

Mahmood N, Chowdhry MA, Kashif M (2003). Genetic analysis of some physio-morphic traits of wheat under drought conditions. J. Genet. Breed. 57:385-391.

Ribaut JM, Hoisington DA, Deutsch JA, Jiang C, Gonzalez DLD (1996). Identification of quantitative trait loci under drought conditions in tropical maize. Flowering parameters and the anthesis to silking interval. Theoret. Appl. Genet. 92:905-914.

Rosegrant MW, Leach N, Gerpacio RV (1999). Alternative future for world cereal and meat consumption. Summer meeting of the Nutrition Society. Guildford, UK. 29June- 2July 1998. Proc. Nutr. Soc. 58:1-16.

Saeed A, Chowdhry MA. Saeed N, Khaliq I, Johar MZ (2001). Line $\times$ tester analysis for some morpho-physiological traits in bread wheat. Int. J. Agric. Biol. 3:444-447.

Sari GM, Villa M, Frova C, Krajewski P, Fonzo ND (1999). Genetic analysis of drought tolerance in maize by molecular markers. II. Plant height and flowering. Theor. Appl. Genet. 99:289-295.

Steel RGD, Torrie JH, Dickey DA (1997). Principles and procedure of statistics. A biometric approach. Mc Graw Hill Book Co., New York, USA. pp. 400-428.

Tabassum MI. Saleem M, Ali A, Malik MA (2005). Genetic mechanism of leaf characteristics and grain yield in maize under normal and moisture stress conditions. Biotechnology 4:243-254.

Tester M, Bacic A (2005). Abiotic stress tolerance in grasses. From model plants to crop plants. Plant Physiol. 137:791-793.

Troyer AF. Openshwa SJ, Knittle KH (1998). Measurement of genetic diversity among popular commercial corn hybrids. Crop Sci. 28:481485. 